\title{
The changing role of libraries in higher education: A symposium at Northern Illinois
}

Academic librarians and university administrators met at Northern Illinois University, DeKalb, on September 17-18, 1984, to identify and discuss the challenges that their libraries will face in the next decade. The NIU symposium was unique in that it offered a forum for both library and university administrators to share their views on campuswide information issues.

"Administrative Perspectives on the Changing Role of Libraries in Higher Education: Critical Issues and Challenges for the $80 \mathrm{~s}$ " was sponsored by the NIU Office of the Provost and the University Libraries. Nineteen pairs of library directors and administrators from universities across the continent participated.

The keynote speakers were Robert Wallhaus, deputy director for academic and health affairs of the Illinois Board of Higher Education; and Roderick T. Groves, deputy director of academic affairs of the Illinois Board of Regents. Both speakers addressed trends in higher education which are affecting academic libraries, including shifts in demography, the increasing use of computer networks, and the impetus for educational reform.

The influence of state legislation was examined by The Honorable Jim Edgar (Illinois Secretary of State and state librarian of Illinois) and E.J. Josey (chief of the Bureau of Library Specialist Services for the New York State Library, and 1984-85 president of ALA). Edgar highlighted the support for resource sharing that the state has given its state university system, making the University of Illinois, Champaign-Urbana, the largest "publicacademic library" in Illinois. An increasingly college-educated public, he said, must have free access to academic library materials through networks housed in local public libraries.

Josey reviewed the history of New York State's aid to research libraries, culminating in this year's $\$ 1.3$ million in annual grants to assist in regional automation projects, and $\$ 1.1$ million in annual grants for preservation and conservation of research materials.

Maurice Glicksman, provost and dean of the faculty at Brown University, and Merrily Taylor, Brown University librarian, spoke on the impact of computer literacy on libraries and librarians. "One byproduct of increasing computer literacy even in such traditional areas as the humanities," Glicksman said, "is more of an interest in interdisciplinary work." Imperatives for change in academic libraries, he added, will be more institutional cooperation and less concern about pride of ownership.

Taylor saw librarians as taking a more active

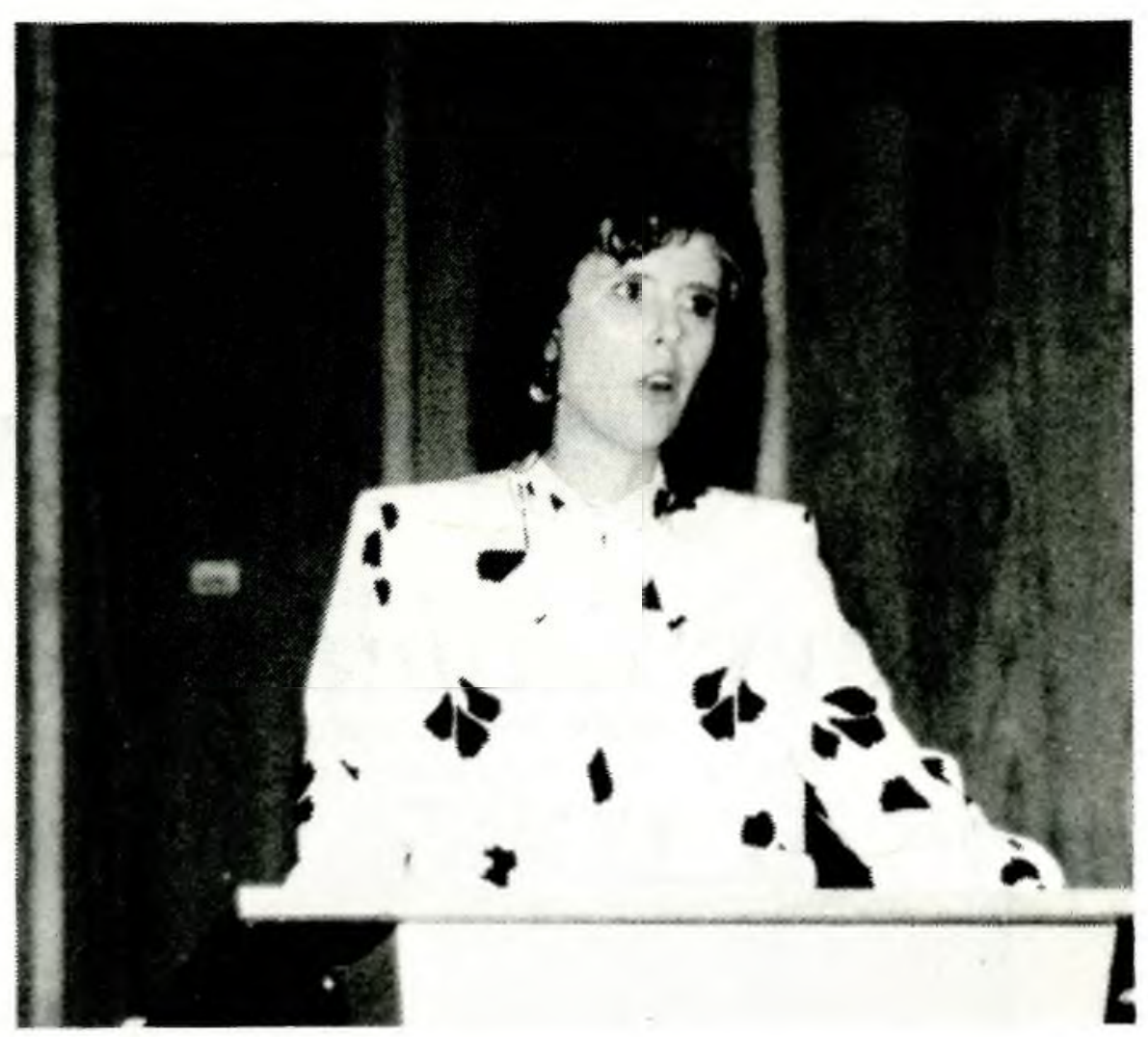

Merrily Taylor at the NIU Symposium.

role in planning for information management. Since they have perhaps a better grasp of reality versus theory in information control, librarians must ensure that new technologies have built into them the safeguards inherent in traditional formats. Will the computer fulfill the scholarly need to browse? Will it be able to access Mark Twain for users who ask for Samuel Clemens? Will current databases be kept for 20 years for future historians? "A librarian's knowledge may be unique in the university," Taylor said, "and may be more important than technical expertise alone."

Theodore Welch, NIU's director of libraries, reviewed the library's crucial ability to compete successfully for available funds. "Each library should have its own fundraising office with a liaison to the campus Office for Development," he said. Welch recommended that someone with library expertise should staff the office, as "it is easier to teach grantsmanship to a librarian than it is to teach library skills to a fundraiser."

The University of Wisconsin-Parkside was represented by Carla Stoffle, who is completing a sixyear tour of duty as assistant chancellor for educational services, and Hannelore Rader, director of the library/learning center. Stoffle emphasized that librarians are still in the library business, which encompasses information management. "Technology will not drastically change what we do," she said, "but it will help advance it." She added that one change might be to fill the academic posts of vice-president for information or computer technology with librarians, especially if there are no qualifying hardware specialists. Rader said that for a library to deal successfully with tech- 
nology it is essential to have good cooperation between the library and the academic administration, a situation that has worked well at Parkside.

Other speakers at the NIU symposium were: Hiroki Kato, professor of Japanese language at Northwestern University, who highlighted the differences between U.S. and Japanese academic faculty; Nancy Brown, university librarian at the University of Saskatchewan, who spoke on the co-existence of hierarchical and collegial governance structures in academic libraries; Joe Boissé, university librarian at the University of California, Santa Barbara, who talked about collective bargaining ("its primary advantage is that it creates a new power base of unionized librarians"); and Paul Vassallo, dean of library services at the University of New Mexico, who emphasized the necessity for adequate planning strategies for academic information systems.

Northern Illinois is exploring the possibility of having another symposium on the same topic some time in the future.

\title{
Higher Education Act revision
}

\section{due in 1985}

\author{
By Nancy Kranich \\ New York University \\ Chair, ACRL Legislation Committee
}

\section{ACRL's Legislation Committee grapples with the definition of a "needy library."}

$\mathbf{T}$ he Higher Education Act will expire on September 30,1985 . Although the Act is subject to automatic extension, it is highly likely to be considered for revision by the next Congress. Several attempts at revision were initiated last year. Caught in a debate over student aid, the bill never moved out of committee. Among the other controversial parts of the bill was the College Library Resources Program (HEA II-A) - a program that was not funded at all in the FY 1984 budget.

The original purpose of Title II-A was to provide grants to academic libraries to assist in the maintenance and improvement of their library collections, and to enable them to share resources and participate in library networks. While the program allotted only $\$ 890$ per institution in FY 1983, it has been authorized to expend up to $\$ 10,000$ per appli- cant. Since its inception in 1966 , over 45,000 awards have been granted, with an annual participation of 2,500 academic libraries, resulting in a cumulative contribution exceeding $\$ 196$ million for acquisitions.

Congressional reluctance to continue to fund HEA II-A has stemmed from a belief that the program must be need-based and not just provide equal and minimal sums of money to any academic library that applies for support. Indeed, many libraries have benefited greatly from this program in the past; those not currently meeting even the minimal standards for adequacy of library resources (estimated at half of all four-year college libraries in a recent analysis) could make significant progress toward upgrading their resources if funds were available once again. A renewed program could 